\title{
Studies on use of Copper Slag as Replacement Material for River Sand in Building Constructions
}

\author{
C. K. Madheswaran • P. S. Ambily • \\ J. K. Dattatreya $\cdot$ N. P. Rajamane
}

Received: 30 January 2012/ Accepted: 7 August 2014/Published online: 20 August 2014

(C) The Author(s) 2014. This article is published with open access at Springerlink.com

\begin{abstract}
This work focuses on the use of copper slag, as a partial replacement of sand for use in cement concrete and building construction. Cement mortar mixtures prepared with fine aggregate made up of different proportions of copper slag and sand were tested for use as masonry mortars and plastering. Three masonry wall panels of dimensions $1 \times 1 \mathrm{~m}$ were plastered. The studies showed that although copper slag based mortar is suitable for plastering, with the increase in copper slag content, the wastage due to material rebounding from the plastered surfaces increases. It is therefore suggested that the copper slag can be used for plastering of floorings and horizontal up to $50 \%$ by mass of the fine aggregate, and for vertical surfaces, such as, brick/block walls it can be used up to $25 \%$. In this study on concrete mixtures were prepared with two water cement ratios and different proportions of copper slag ranging from $0 \%$ (for the control mix) to $100 \%$ of fine aggregate. The Concrete mixes were evaluated for workability, density, and compressive strength.
\end{abstract}

Keywords Copper slag · Bricks .

Ordinary Portland cement $\cdot$ Sand $\cdot$ Plastering $\cdot$ Mortar

\section{Introduction}

Copper slag is by product of the manufacture of copper [1-4]. Large amount of copper slag are generated as waste worldwide during the copper smelting process. The world

C. K. Madheswaran (ه) P. P. S. Ambily ·

J. K. Dattatreya · N. P. Rajamane

CSIR-Structural Engineering Research Centre, CSIR Campus,

Taramani, Chennai 600113, India

e-mail: ckm@serc.res.in copper production is currently about 14.98 million tons (International Copper Study Group, 2005) and it is estimated that for every ton of copper produced, about 2.2tons of copper slag is generated as a waste [5]. Many researches have been carried out studies on long-term stability of the slag in sea water [6]. Chemical analysis of copper slag shows that copper content is limited to 0.5 to $2 \%$. Major constituents are iron, silica, alumina and calcium oxide. However, using sea water as the leachant, (i), mechanical activation of slag followed by extraction test using sea water as leachant, (ii) pressure leaching of the slag (at 1000psi) in $\mathrm{N}_{2}$ and $\mathrm{O}_{2}$ for $4 \mathrm{~h}$ at different temperatures. The leachability of most of the heavy metals of the unmilled slag in seawater even after 13 stages of multiple extraction is small and not significant. It was observed that the amount of dissolution of most of the heavy metals in seawater from both the unmilled and the activated slag samples are significantly lower in pressure leaching under both pure nitrogen and oxygen compared to the total dissolution observed after 13 cycles of exctraction in the MEP. The researchers have carried out studies on engineering properties of copper slag-flyash-polime mix and its utilization in base course of flexible pavements [7-9]. The main objective of the present study is to quantify the influence of important factors such as fly ash, dolime content and curing period on the strength and stiffness characteristics of copper slag. Many research works have been carried out studies on leachability studies on copper slag $[10,11]$. Copper slag was subjected to leaching studies in three aquacy media (Tap water, Rain water and Seawater). $\mathrm{PH}$ value are 7.2, 2.4 and 8.68 corresponding to Tap water, rain water and sea water respectively. Copper slag samples were dipped in distilled water and studied for leaching of heavy metals from them up to a period of 15 days using ICP technique. No leaching of heavy metals 
such as $\mathrm{Pb}, \mathrm{Zn}, \mathrm{Cr}$, Ni, Mo etc., was observed. Leaching of very small quantities of $\mathrm{Ba}(0.008 \mathrm{ppm}), \mathrm{Cu}(0.087 \mathrm{ppm})$, $\mathrm{Mn}$ (0.008 ppm) and $\mathrm{Sr}(0.002 \mathrm{ppm})$ was however observed at 15 days. The leaching of heavy metals in copper slag samples was tested by National Council for Cement and Building Materials, New Delhi as per the method given in ASTM D-5233-1995d which involves sample treatment under aggressive conditions. The results indicate that the leaching of heavy metals was well below the toxicity limits even under aggressive conditions. The leachant studies revealed that the addition of slag does not pave way for leaching of harmful elements like Copper $(\mathrm{Cu})$ and Iron $(\mathrm{Fe})$ present in slag in concrete. Thus, it does not pose any environmental problem [11].

This slag is currently being used for many applications utilise only about $15-20 \%$ of the copper slag generated. The remaining material used from land-filling to grit blasting, which are not very high value added applications. This is dumped as a waste, which requires large areas of land, a fast diminishing high value asset. Alternative use of it as partial or complete substitute for fine aggregates in concrete will eliminate these problems. Hence a study was undertaken to find the effect of replacement of sand by copper slag in brick masonry construction and in cement concrete.

Plastering over brick/concrete masonry is a common practice often adopted in masonry and concrete construction unless the actual brick/block appearance is required. With the scarcity of conventional sand, search for alternative materials is on the increase. A study was also made on the feasibility of copper slag as partial replacement of river sand for cement mortar as plastering material (for repair and new constructions) conventional clay brick specimens plastered with cement, sand and copper slag mortar. This cement paste portion determines the characteristics properties of cement mortar, in fresh and hardened stages.

\section{Scope of the Study}

The main objective is to study the feasibility of use of copper slag as fine aggregate in cement mortar jointing material in brick masonry construction and cement concrete. The scope of the work includes the studies on the following aspects of cement mortar and cement concrete:

- Evaluation of copper slag based cement mortar in brick masonry construction

- The percentage of copper slag used for replacement of river sand are 0, 25, 50 and $75 \%$

- Cement sand mortar joint thickness of 10 and $15 \mathrm{~mm}$
- Plaster ability of use of copper slag for partial replacement material for river sand

- Use of copper slag as replacement material for river sand in cement concrete $(0,25,50,75$ and $100 \%)$

\section{Materials}

\section{Cement and Copper Slag}

In the present investigation, ordinary Portland cement of 53 grade was used. Fine aggregate used for control mortar and concrete was natural river sand. Coarse aggregate consists of crushed stone aggregate of $20 \mathrm{~mm}$. Copper slag is a byproduct material produced from the process of manufacturing copper. Copper slag used in this work was brought from Sterlite Industries Ltd, Tuticorin, Tamil Nadu, India. Physical and chemical properties of copper slag are presented in Table 1.

\section{Experimental Investigation}

\section{Mix Design and Sample Preparation for Brick Masonry Prisms}

The mix proportion used for this study is given in Table 2. Eight cement mortar mixes with different proportions of copper slag ranging from $0 \%$ (for the control mix) to $75 \%$ were considered. The cement mortar with mix ratio (cement: sand) of 1:3 and 1:5 was prepared. Figure 1 shows the experimental setup for static test on stack bonded masonry units. Stack bonded masonry units were prepared using five numbers of clay wire cut bricks of dimensions are $226 \times 106 \times 72 \mathrm{~mm}$ by arranging them one above the other as shown in Fig. 1. The flow study was carried out to determine the water cement ratios to be used

Table 1 Physical and chemical properties of copper slag

\begin{tabular}{ll}
\hline Composition & $\%$ By mass \\
\hline $\mathrm{Fe}_{2} \mathrm{O}_{3}$ & $55-60$ \\
$\mathrm{Fe}_{3} \mathrm{O}_{4}$ & $<10$ \\
$\mathrm{SiO}_{2}$ & $27-33$ \\
$\mathrm{CaO}$ & $1-3.5$ \\
$\mathrm{~S}$ & $0.2-1.5$ \\
$\mathrm{Cu}$ & $<1$ \\
$\mathrm{Al}_{2} \mathrm{O}_{3}$ & $<3$ \\
\hline
\end{tabular}

Specific gravity (SSD): 4.12, Bulk density (SSD): 2.31 g/cc Fineness modulus: 3.4, Deleterious Materials: Not present 
Table 2 Mix proportions of cement mortar containing copper slag used for masonry joints

\begin{tabular}{llclll}
\hline Mix no. & $\begin{array}{l}\text { Mix Id } \\
\text { Cement: copper slag: sand }\end{array}$ & $\begin{array}{l}\text { \% copper slag content } \\
\text { in fine aggregate }\end{array}$ & $\begin{array}{l}\text { Mix ratio cement: } \\
\text { fine aggregate }\end{array}$ & $\begin{array}{l}\text { Compressive } \\
\text { strength, MPa }\end{array}$ & $\begin{array}{l}\text { Water-cement } \\
\text { ratio }\end{array}$ \\
\hline 1 & M1:3 (SA100) & 0 & $1: 3$ & 11 & 0.70 \\
2 & M1:0.75:2.25 (SC75) & 25 & $1: 0.75: 2.25$ & 12 & 0.65 \\
3 & M1:1.5:1.5 (SB50) & 50 & $1: 1.5: 1.5$ & 13.6 & 0.60 \\
4 & M1:2.25:0.75 (SD25) & 75 & $1: 2.25: 0.75$ & 13 & 0.55 \\
5 & M1:5 (SA100) & 0 & $1: 5$ & 5.4 & 1.15 \\
6 & M1:1.25:3.75 (SC75) & 25 & $1: 1.25: 3.75$ & 5.9 & 0.95 \\
7 & M1:2.5:2.5 (SB50) & 50 & $1: 2.5: 2.5$ & 6.9 & 0.92 \\
8 & M1:3.75:1.25 (SD25) & 75 & $1: 3.75: 1.25$ & 6.5 & 0.85 \\
\hline
\end{tabular}

Test specimen: $50 \times 100 \mathrm{~mm}$ cylinder

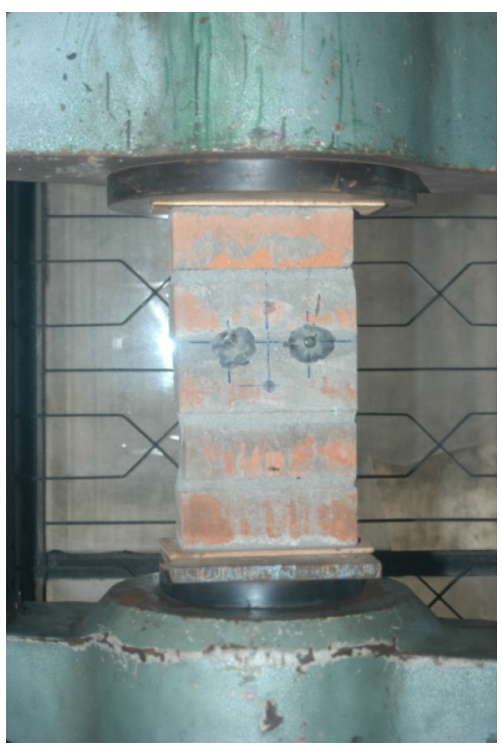

Fig. 1 Experimental set-up for static test (Brick masonry prisms)

for the jointing cement mortar. For the cement mortar mix of $1: 3$, the content of copper slag were varied from 0,25 , 50 and $75 \%$ of the fine aggregate by mass as shown in Table 2.

\section{Testing of Individual Bricks}

The compressive strength, water absorption and initial rate of absorption of individual bricks were carried out. The water absorption of brick specimens were carried out as per IS 3495 Part 2. The results are presented in Tables 3. The compressive strength of individual brick is $24.7 \mathrm{MPa}$ and water absorption is $5 \%$.

\section{Testing of Brick Masonry Prism}

The compression tests on brick masonry units were conducted using a 1,000 kN Universal Testing Machine
Table 3 Properties of bricks

\begin{tabular}{lll}
\hline Property & $\begin{array}{l}\text { Number of } \\
\text { specimens } \\
\text { tested }\end{array}$ & $\begin{array}{l}\text { Wire-cut } \\
\text { bricks }\end{array}$ \\
\hline Size, $\mathrm{mm}$ & 20 & $226 \times 106 \times 72$ \\
Water absorption $(24 \mathrm{~h})$ & 6 & $5 \%$ \\
IRA, $\mathrm{kg} / \mathrm{m}^{2} / \mathrm{min}$ & 6 & 1.39 \\
Wet compressive strength, MPa & 6 & 24.70 \\
\hline
\end{tabular}

(UTM). A $3 \mathrm{~mm}$ thick plywood sheet was placed between top and bottom of the specimen below $25 \mathrm{~mm}$ thick steel plates. Compression tests on stack bonded brick masonry prisms were conducted as recommended by ASTM (1992, 2007) and Bureau of Indian Standards (1987) codes. The specimen was instrumented for measurement of deformation by a dial gauge and compressive strain by a Pfender gauge. The specimens were subjected to incremental static loading. Deflections at midpoint were measured at regular intervals of load using dial gauges. Longitudinal strains were also recorded at regular intervals of load using a Pfender gauge of least count $10 \mu \mathrm{m}$ strains. The important test results are summarised in Table 4. The compressive strengths of brick masonry prisms are given as ranges of strength rather than expressing it in terms of average strength. This is because of the greater variability normally encountered in testing of brick masonry.

To determine the compressive strength of cement mortar used for the brick masonry joints, 10 cylinders $(50 \mathrm{~mm}$ diameter, $100 \mathrm{~mm}$ length) were cast for each mix, and 10 samples each were tested after 28-days of curing. 28 day compressive strength test was conducted in accordance with IS: 516-1959. All strength tests were conducted using $400 \mathrm{kN}$ compression testing machine. Mortar strength of cylinders are presented in Table 5. 
Table 4 Results of brick masonry

\begin{tabular}{llllll}
\hline S1 No & Specimen ID & \% of copper slag & Mix ratio & Mortar thickness, mm & Compressive strength, MPa \\
\hline 1 & M1:3 (SA100) & 0 & $1: 3$ & 10 & $10.1-10.8$ \\
2 & M1:0.75:2.25 (SC75) & 25 & $1: 3$ & 10 & $13.5-15.8$ \\
3 & M1:1.5:1.5 (SB50) & 50 & $1: 3$ & 10 & $15-18.4$ \\
4 & M1:2.25:0.75 (SD25) & 75 & $1: 3$ & 10 & $11.7-13.5$ \\
5 & M1:5 (SA100) & 0 & $1: 5$ & 10 & $9.5-9.9$ \\
6 & M1:1.25:3.75 (SC75) & 25 & $1: 5$ & 10 & 13.5 \\
7 & M1:2.5:2.5 (SB50) & 50 & $1: 5$ & 10 & 13.58 \\
8 & M1:3.75:1.25 (SD25) & 75 & $1: 5$ & 10 & $11.6-14.28$ \\
9 & M1:3 (SA100) & 0 & $1: 3$ & 15 & $9.8-10.5$ \\
10 & M1:0.75:2.25 (SC75) & 25 & $1: 3$ & 15 & $14.48-15.19$ \\
11 & M1:1.5:1.5 (SB50) & 50 & $1: 3$ & 15 & $16-18.4$ \\
12 & M1:2.25:0.75 (SD25) & 75 & $1: 3$ & 15 & $11.66-19$ \\
13 & M1:5 (SA100) & 0 & $1: 5$ & 15 & $9.4-9.7$ \\
14 & M1:1.25:3.75 (SC75) & 25 & $1: 5$ & 15 & 11.70 \\
15 & M1:2.5:2.5 (SB50) & 50 & $1: 5$ & 15 & $12-12.89$ \\
16 & M1:3.75:1.25 (SD25) & 75 & $1: 5$ & 15 & $11.28-11.7$ \\
\hline
\end{tabular}

Table 5 Plaster ability of cement mortars incorporating copper slag

\begin{tabular}{|c|c|c|c|c|c|}
\hline S1 No & $\begin{array}{l}\text { Type of } \\
\text { plaster }\end{array}$ & $\begin{array}{l}\text { Proportions (cement: sand: } \\
\text { copper slag: water) }\end{array}$ & $\begin{array}{l}\text { Average compressive } \\
\text { strength, MPa }\end{array}$ & Flow, mm & Observations \\
\hline 1 & Wall plaster & $1: 3: 0: 0.68$ & 12 & 210 & $\begin{array}{l}5 \% \text { rebound, sticky mix, good bonding to brick } \\
\text { surface, fast drying, good for sponge finish }\end{array}$ \\
\hline 2 & Wall plaster & $1: 2.25: 0.75: 0.62$ & 14 & 220 & $\begin{array}{l}25 \% \text { rebound, less sticky, satisfactory bonding, } \\
\text { satisfactory for sponge finish }\end{array}$ \\
\hline 3 & Wall Plaster & $1: 1.5: 1.5: 0.57$ & 18 & 210 & $\begin{array}{l}35 \% \text { rebound, less sticky, difficulty in bonding, } \\
\text { slow drying, not good for sponge finish }\end{array}$ \\
\hline 4 & Wall plaster & 1:4:.0:0:0.78 & 9 & 210 & $\begin{array}{l}10 \% \text { rebound, sticky mix, good bonding to brick } \\
\text { surface, fast drying, good for sponge finish }\end{array}$ \\
\hline 5 & Wall plaster & $1: 3: 1: 0.72$ & 11 & 220 & $\begin{array}{l}32 \% \text { rebound, less sticky, satisfactory bonding, } \\
\text { satisfactory for sponge finish }\end{array}$ \\
\hline 6 & Wall Plaster & $1: 2: 2: 0.67$ & 12 & 210 & $\begin{array}{l}45 \% \text { rebound, less sticky, difficulty in bonding, } \\
\text { slow drying, not good for sponge finish }\end{array}$ \\
\hline 7 & Ceiling Plaster & $1: 3: 0: 0.71$ & 11 & 250 & $\begin{array}{l}20 \% \text { wastage, Needs cement slurry bond coat to } \\
\text { stick, fast drying, good finish }\end{array}$ \\
\hline 8 & Ceiling Plaster & 1:2.250.75:0.69 & 10 & 250 & $\begin{array}{l}40 \% \text { wastage, Needs cement slurry bond coat to } \\
\text { stick, less bond, slow drying, finish not } \\
\text { satisfactory }\end{array}$ \\
\hline
\end{tabular}

\section{Experimental Studies on use of Copper Slag as Replacement Material for River Sand in Cement Concrete}

\section{Mix Design and Sample Preparation}

The mix proportion used for this study is given in Table 6. Ten concrete mixes with different proportions of copper slag ranging from $0 \%$ (for the control mix) to $100 \%$ were considered. The materials were weighed using a digital balance. The materials were mixed in a pan mixer. The mixes were compacted using vibrating table. The slump of the fresh concrete was determined to study the effect of copper slag replacement on the workability of concrete. The specimens were demoulded after $24 \mathrm{~h}$, cured in water and then tested in saturated surface dry condition at the required age.

\section{Testing}

To determine the compressive strength, eight cubes $(150 \times 150 \times 150 \mathrm{~mm})$ were cast for each mix, and four samples each were tested after 7 and 28-days of curing. 7 and 
Table 6 Mix proportions of concrete mixes

\begin{tabular}{|c|c|c|c|c|c|c|}
\hline \multicolumn{7}{|c|}{ Mix proportions, $\mathrm{kg} / \mathrm{m}^{3}$} \\
\hline & Cement & Sand & $10 \mathrm{~mm}$ agg. & $20 \mathrm{~mm}$ agg. & Water & w/c ratio \\
\hline $\mathrm{CC} 1$ & 413 & 837 & 384 & 576 & 190 & 0.46 \\
\hline $\mathrm{CCII}$ & 346 & 885 & 384 & 576 & 190 & 0.55 \\
\hline
\end{tabular}

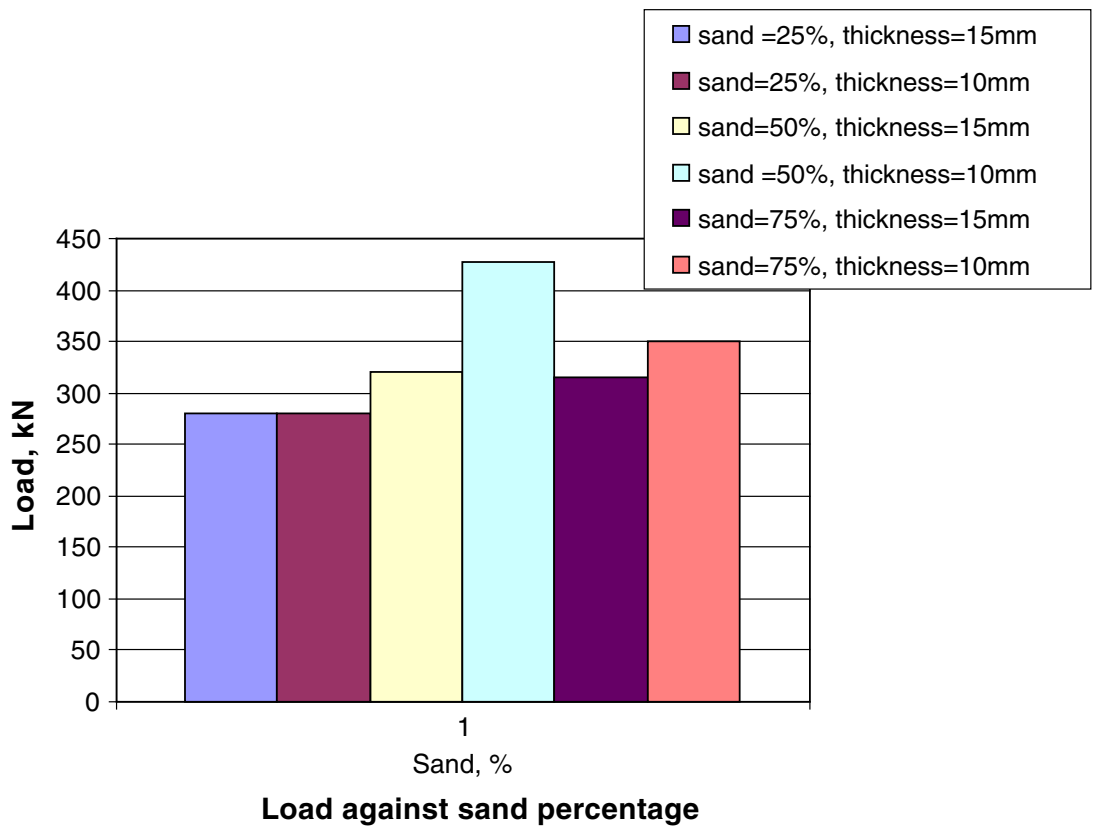

Fig. 2 Load vs percentage of volume of sand content in jointing mortar-brick masonry prisms

28 day cube compressive strength test was conducted in accordance with IS: 516-1959. All strength tests were conducted using 1,000 kN compression testing machine Fig. 1.

\section{Results and Discussion}

\section{Physical Properties}

The specific gravity and density of copper slag and river sand were determined in accordance with IS 2386 part III. Copper slag has a specific gravity of 4.12 and bulk density of $2.31 \mathrm{~g} / \mathrm{cc}$ which is higher than that for normal river sand $(2.6,1.53 \mathrm{~g} / \mathrm{cc})$ which may result in production of concrete with higher density. Also, the measured water absorption for copper slag was $0.40 \%$ compared with $0.83 \%$ for sand. This suggests that copper slag has less surface porosity and would demand less water than that required by sand in the concrete mix. Therefore due to the free water content in concrete matrix and also due to the higher coarseness of copper slag will increase the workability of the concrete as the copper slag content increases. Figure 3 shows sieve analysis as per IS 383: 1970 test results

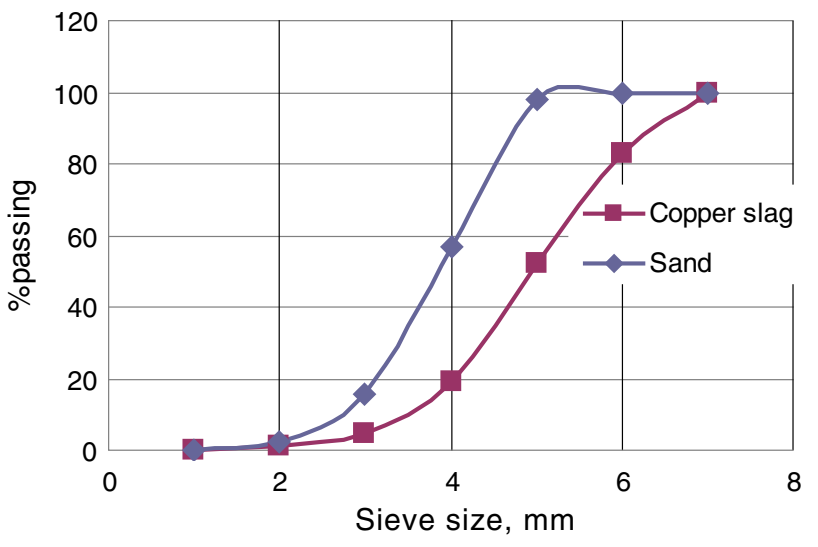

Fig. 3 Sieve analysis of sand and copper slag

conducted, it seems that river sand has higher fines content than copper slag.

\section{Effect of Copper Slag on the Workability and Density} of Concrete

The effect of copper slag as fine aggregates on the workability and density of concrete is presented in Table 7 for 
different proportions of copper slag. The workability of concrete was determined based on the measured slump of the fresh concrete. It is clear from Fig. 5 that the workability of concrete increases with the addition of copper slag in the concrete mixes. This increase in the workability with the copper slag is attributed to the low water absorption characteristics of copper slag. This increase in the workability may have beneficial effect on concrete in the sense that mixes with low water-to-cement ratios, for the same amount of sand replaced, concrete can be produced which may have good workability, greater strength than the conventional concrete. However, it should be noted that mixes with high contents of copper slag (i.e. Mixes 5 and 10) showed signs of bleeding and segregation which can have detrimental effects on concrete performance. However this can be corrected by addition of finer materials such as fly ash, quarry dust etc. In the case of higher percentage replacement it is noticed that there is a reduction in workability this may be due to the packing effect.

In general there is an increase in the density of concrete with the increase of copper slag quantity. The density of concrete was increased by $9-19 \%$. This is mainly due to the higher specific gravity of copper slag which was 4.12 compared with sand which has a specific gravity 2.6.

\section{Effect of Copper Slag on the Strength of Concrete}

The average 7 and 28 day compressive strengths for different concrete mixes are shown in Fig. 4. The results show that the compressive strength of copper slag concrete is slightly increased when compared to control concrete (around $19 \%$ ), where as copper slag quantity increases the strength is more or less same (Figs. 4, 5).
As in the case of control concrete, for copper slag concrete when the water cement ratio increases the strength reduces. As seen from Fig. 2, irrespective of water-cement ratio, as the copper slag content increases, the compressive strength increases. The highest compressive strength was achieved by Mix 3 (Table 7) with $50 \%$ replacement of copper slag, which was found about $43 \mathrm{MPa}$ compared with $35 \mathrm{MPa}$ for the control mixture. The increase in the strength was almost $19 \%$ compared to the control mix. However, the increase in compressive strength of copper slag based concrete over control concretes was almost of the same order for all copper slag contents investigated in the study. Therefore, if the concrete mixes are proportioned by absolute volume method and the percentage of replacement of river sand is by mass of the total fine aggregate, the compressive strength is influenced mainly by the water-cement ratio. The above observations are supported by the work of other researchers who studied the influence of copper slag as fine and coarse aggregates on the strength of both normal and high-strength concrete. The results indicated that the compressive strengths of concrete made with copper slag are slightly higher than that of the control mixtures. Based on the analysis of results, it was indicated that the upper limit for sand replacement by Copper slag is $50 \%$ for conventional grades of concrete and $75 \%$ for high strength concrete.

\section{Results of Brick Masonry}

\section{Effect of Copper Slag on the Water Cement Ratio} of Cement Mortar

The water cement ratio of the mortar mixes was determined based on the flow study carried out on fresh mortar. It is

Table 7 Properties of concrete at 7- and 28-days of curing

\begin{tabular}{|c|c|c|c|c|c|c|}
\hline \multirow[t]{2}{*}{ Mix no. } & \multirow[t]{2}{*}{ Mix ID } & \multirow[t]{2}{*}{ Mixtype } & \multirow[t]{2}{*}{ Fresh concrete density, $\mathrm{kg} / \mathrm{m}^{3}$} & \multirow[t]{2}{*}{ Slump, mm } & \multicolumn{2}{|c|}{ Strength, $\mathrm{MPa}$} \\
\hline & & & & & fc7 & fc 28 \\
\hline 1 & $\mathrm{CCI}$ & Control $(100 \% \mathrm{~S})$ & 2,430 & 25 & 25 & 35 \\
\hline 2 & $\mathrm{CU}_{25} \mathrm{I}$ & $25 \% \mathrm{CS}+75 \% \mathrm{~S}$ & 2,624 & 80 & 26 & 41 \\
\hline 3 & $\mathrm{CU}_{50} \mathrm{I}$ & $50 \% \mathrm{CS}+50 \% \mathrm{~S}$ & 2,696 & 75 & 28 & 43 \\
\hline 4 & $\mathrm{CU}_{75} \mathrm{I}$ & $75 \% \mathrm{CS}+25 \% \mathrm{~S}$ & 2,818 & 60 & 27 & 40 \\
\hline 5 & $\mathrm{CU}_{100} \mathrm{I}$ & $100 \% \mathrm{CS}$ & 2,890 & 35 & 26 & 41 \\
\hline 6 & CCII & Control $(100 \% \mathrm{~S})$ & 2,405 & 25 & 17 & 22 \\
\hline 7 & $\mathrm{CU}_{25} \mathrm{II}$ & $25 \% \mathrm{CS}+75 \% \mathrm{~S}$ & 2,620 & 150 & 18 & 27 \\
\hline 8 & $\mathrm{CU}_{50} \mathrm{II}$ & $50 \% \mathrm{CS}+50 \% \mathrm{~S}$ & 2,711 & 65 & 21 & 29 \\
\hline 9 & $\mathrm{CU}_{75} \mathrm{II}$ & $75 \% \mathrm{CS}+25 \% \mathrm{~S}$ & 2,815 & 45 & 21 & 31 \\
\hline 10 & $\mathrm{CU}_{100} \mathrm{II}$ & $100 \% \mathrm{CS}$ & 2,940 & 30 & 20 & 30 \\
\hline
\end{tabular}

$F c$ cube compressive strength, $S$ sand, $C S$ copper slag

$f_{c} 7$ cube compressive strength, Cured

$f c 7 f c 28$-cube compressive strength at 7 th and 28 th days 


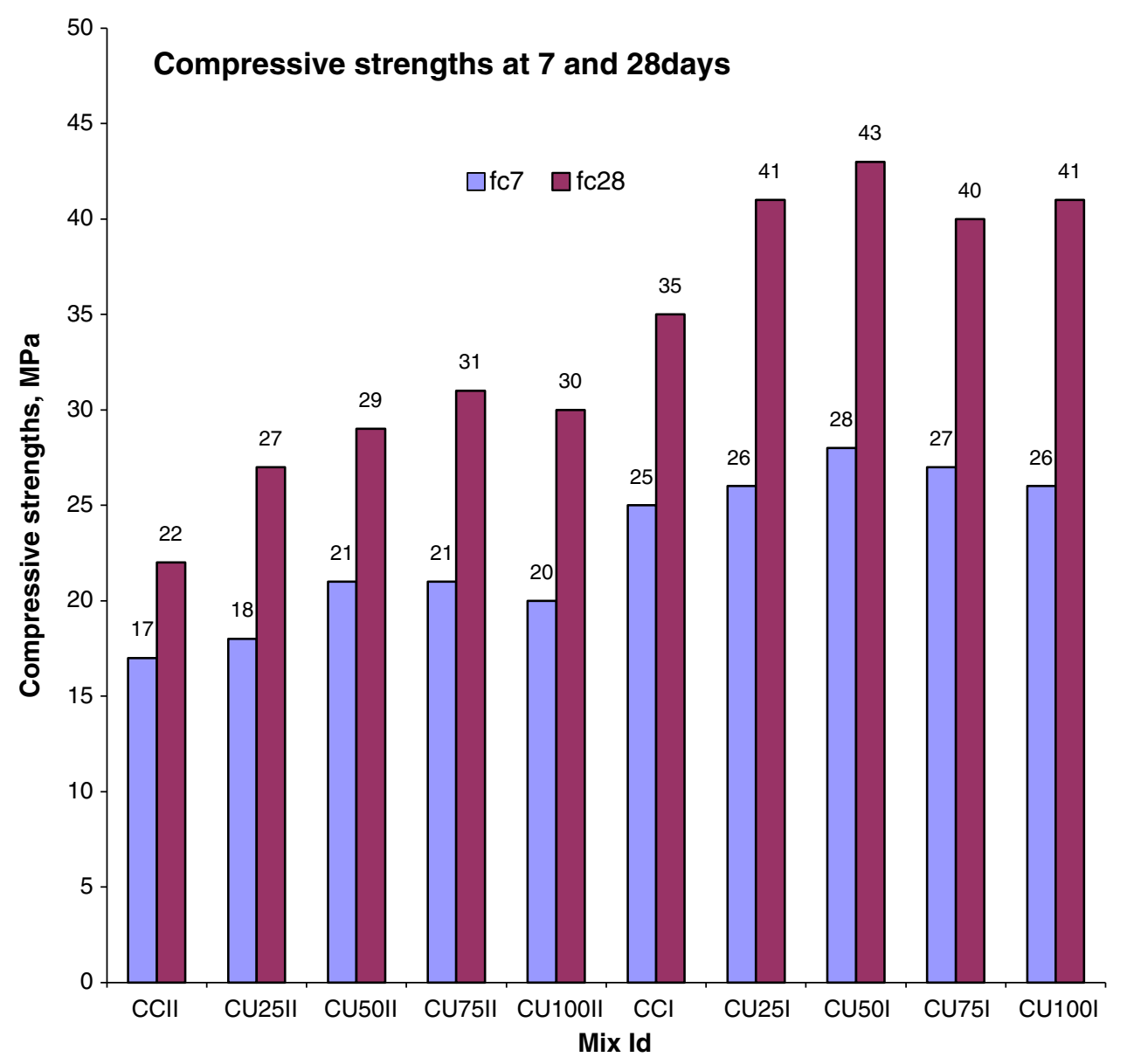

Fig. 4 Average cube compressive strength of concrete at 7 and 28 days of curing

\section{Relationship between workability and compressive strength of}

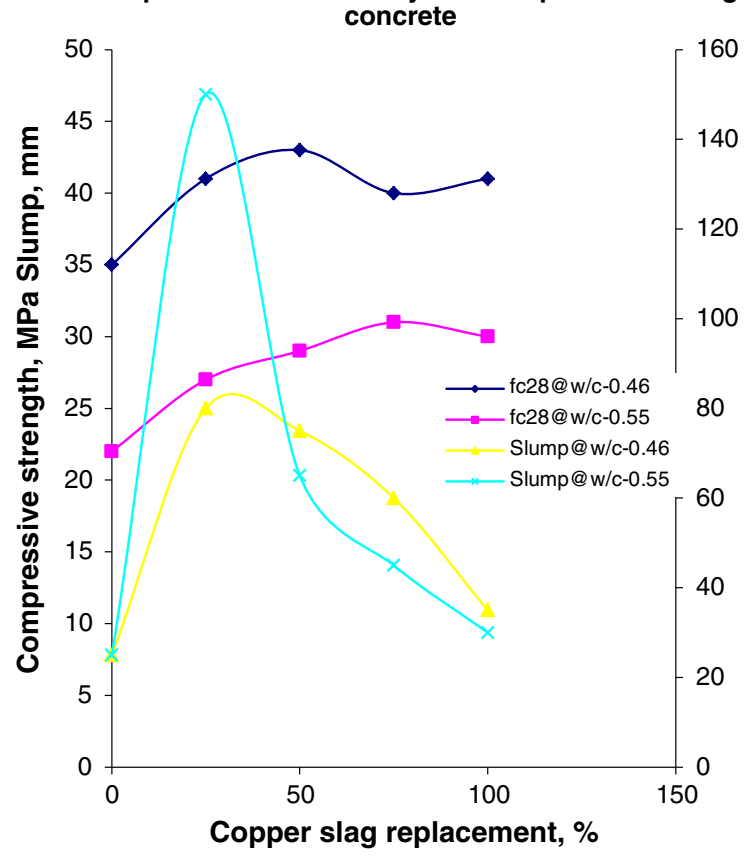

Fig. 5 Relationship between workability and strength of concrete clear from Table 4 that the water cement ratio decreases with the addition of copper slag in the cement mortar. This decrease in the water cement ratio of cement mortar with the addition of copper slag is attributed to the low water absorption characteristics of copper slag. This is mainly due to the higher specific gravity of copper slag which was 4.12 compared with sand which has a specific gravity of 2.6.

\section{Effect of Copper Slag on the Compressive Strength} of Brick Masonry Prisms

Prismatic stack bonded brick masonry specimens cast with copper slag mortar as jointing material is tested for compression. The properties of bricks are presented in Table 3. The compressive strength of individual brick is $24.7 \mathrm{MPa}$ and water absorption is $5 \%$. The results of brick masonry prisms are presented in Table 4. Figure 2 shows the bar graph of load vs percentage volume of sand replaced by copper slag. The highest compressive strength of brick masonry prisms varies from 15 to $18.54 \mathrm{MPa}$ for the mix with $50 \%$ of sand replaced with $50 \%$ of copper slag. The highest compressive strength was obtained for the mix $3(1: 1.5: 1.5)$ with $50 \%$ of sand and $50 \%$ of copper slag. 
Based on the test results, it was observed that specimen with $50 \%$ copper slag and $50 \%$ sand are more efficient than other specimens and it was recommended that use of copper slag is $50 \%$ as replacement of conventional river sand is the most feasible alternative. The above observations are supported by the work of other researchers who studied the influence of copper slag as fine and coarse aggregates on the strength of both normal and highstrength concrete. The results indicated that the compressive strengths of concrete made with copper slag are slightly higher than that of the control mixtures. The compressive strength of mortars and concrete specimens containing copper slag as fine aggregate was investigated by many researchers and the study concluded that the mortars containing the larger amounts of copper slag with $20-80 \%$ substitution of copper slag as fine aggregate had the strengths higher than that of the control specimens [12]. Many investigators have conducted and also showed that the use of copper slag aggregate compared to limestone aggregate resulted in a 28-day compressive strength improvement of about 10-15\% [2]. Therefore, copper slag can be beneficially used as partial replacement for river sand as a fine aggregate in brick masonry construction.

\section{Studies on Plastering of Brick Masory}

\section{Experimental Work}

A study on use of copper slag as sand replacement material for plastering of brick masonry and structural concrete (ceiling plaster) was undertaken. Figure 6 shows the plastering of copper slag based cement mortar on brick masonry walls. The fine aggregate used for plastering work was sieved through $2.36 \mathrm{~mm}$ is sieve and only the portion passing through the sieve was used for the work. To carry out this job, the existing brick surface was roughened with wire brushes and cleaned by water spray. To fix the water cement ratio suitable for plastering work, trials were carried out involving the services of a skilled mason to assess the consistency of the mix.

Three panels of dimensions $1 \times 1 \mathrm{~m}$ were plastered. For ceiling plaster, 1:3 cement mortar with zero and $25 \%$ copper slag was investigated. Weighed quantities of cement, sand, copper slag were taken and blended by hand mixing. Weighed quantity of water was added to the mixture and uniformly mixed and the suitability of the mix was tested by the mason for plastering by dashing the blended mixture against the wet prepared brick surface. Trials were continued by adding more quantity of measured water until the dashed mortar stuck to the prepared surface. At this stage the trials were stopped and the total quantity of water added was summed up. The ceiling plaster was applied to the under-

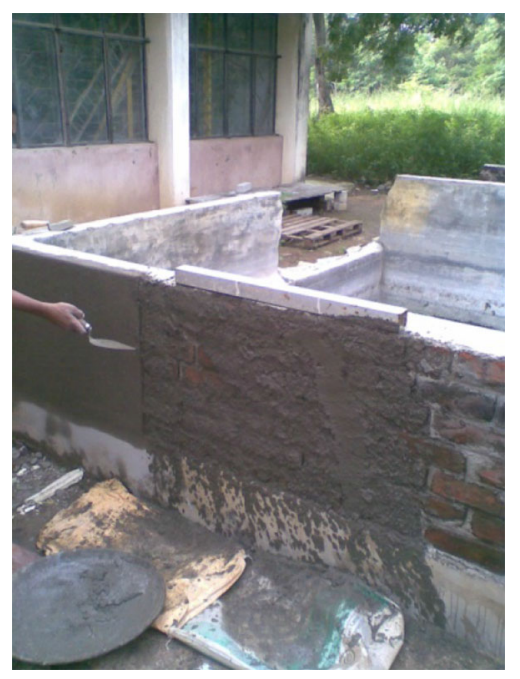

Fig. 6 Plastering of vertical surface of brick masonry wall

surface of a hardened concrete slab after preparing the surface by light hacking with a chisel and spray wetting with water. The consistency of the mix was the same as that adopted for a vertical brick surface except that the concrete surface was coated with thin cement slurry to improve the bond. However, copper slag was found not suitable for use in mortar used for ceiling plaster.

\section{Discussion of Results of Ceiling, Horizontal and Vertical Surfaces of Plastering}

The results of the study are presented in Table 5. The studies show that copper slag can be used in cement mortar as a plastering material for horizontal and vertical surfaces, such as brick/block walls. However with increase in copper slag content, the wastage due to material rebounding from the plastered surfaces increases. The wastage is attributed to the greater specific gravity and higher particle size of copper slag, which reduces the cohesiveness and reduced wettability due to increased contact angle compared to ordinary plastering mortar. The greater hardness and mass density of copper slag also caused increased rebound. The observations on the plasterability of the mix are indicated in Table 5.

Therefore, it is recommended that copper slag can be used for plastering of floorings and horizontal surfaces up to a maximum of $50 \%$ by mass of the fine aggregate, and for vertical surfaces, such as, brick/block walls the maximum limit shall be $25 \%$.

\section{Conclusion}

The following conclusions may be drawn from the present study 
- The behaviour of copper slag seems to be similar to river sand for its use as fine aggregate in mortar. However minor adjustment/modifications may have to be made in view of the higher specific gravity and rough surface texture and the extent of copper slag proposed to be used.

- From the brick masonry strength considerations, the copper slag has been often found to be beneficial. The present study utilised the clay bricks which were stronger than the mortar of the joint. Generally, the strengths of the bricks available in India are very often, much less than that used in preparing test specimens of the present investigation. Hence, the conclusions given here can be conservatively applied to most of the clay brick masonry constructions in India.

- Copper slag can be used as a sand replacement material for plastering of floorings and horizontal surfaces up to $50 \%$ by mass of the total fine aggregate, and this can be reduced up to $25 \%$ by mass of the fine aggregate for vertical surfaces, such as, brick/block walls. However, Copper slag is not suitable for use in ceiling plaster. Generally, fine aggregate passing $2.36 \mathrm{~mm}$ sieve is suitable for plastering.

- Compared to the control mix, for copper slag based concrete, there is an increase in the density up to $19 \%$, whereas the workability was found to be slightly better for the mixes investigated in the present study.

- The highest compressive strength obtained was $43 \mathrm{MPa}$ (50\% replacement), the corresponding strength for control concrete was $35 \mathrm{MPa}$. The full replacement of sand by copper slag yielded higher compressive strength compared to that of the control mix. However, with different replacements the variation in strength was marginal.

- Based on the analysis of results, It was indicated that the upper limit for sand replacement by copper slag is $50 \%$ for conventional grades of concrete and $75 \%$ for high strength concrete.

- Physico-mechanical and chemical characteristics of copper slag lead to its utilisation to prepare various value added products such as cement, filler, ballast, aggregates, abrasive and granular material. The leachability of most of the heavy metals of the unmilled slag in seawater even after 13 stages of multiple extraction is small and not significant.
Acknowledgments The authors are thankful to CSIR-Structural Engineering Research Centre (SERC), Chennai, India and Sterlite Industries India Limited (SIIL), Tuticorin, Tamil Nadu, India for their guidance and support.

Open Access This article is distributed under the terms of the Creative Commons Attribution License which permits any use, distribution, and reproduction in any medium, provided the original author(s) and the source are credited.

\section{References}

1. S. Caliskan, A. Behnood, Recycling Copper Slag as Coarse Aggregate: Hardened Properties of Concrete, in Proceedings of Seventh International Conference on Concrete Technology in Developing Countries Malaysia (2004), pp. 91-98

2. M. Khanzadi, A. Behnood, Mechanical properties of highstrength concrete incorporating copper slag as coarse aggregate. Constr. Build. Mater. 23, 2183-2188 (2009)

3. T. Ayano, O. Kuramoto, K. Sakata, Concrete with copper slag as fine aggregate. J. Soc. Mater. Sci. Jpn. 49(10), 1097-1102 (2000)

4. F. Li, Test research on copper slag concrete. J. Fuzhou Univ. 127(5), 59-62 (1999). Natural Science Edition

5. B. Gorai, R.K. Jana, Premchand, Characterisatics and utilization of copper slag a review. Resour. Conserv. Recycl. 39(4), 299-313 (2003)

6. P. Shanmuganathan, P. Lakshmipathiraj, S. Kumar, A. Sumathy, S. Srikanth, Stability of copper smelter slag in sea water. Environ. Prog. Sustain. Energy 31(1), 68-76 (2012)

7. J. Shahu, S. Patel, A. Senapat, Engineering properties of copper slag-fluash-polime mix and its utilization in base course of flexible pavements, J. Mater Civ. Eng. (2012) doi: 10.1061/(ASCE)MT.1943-5533.0000756

8. H. Hassan, K. AI-Jabri, Laboratory evaluation of hot-mix asphalt concrete containing copper slag aggregate. J. Mater. Civ. Eng. 23(6), 879-885 (2011)

9. K.S. Al-jabri, H. Al-oraimi, A.S. Alnuaimi, Copperslag as fine aggregate for high performance concrete. TJER 9(2), 90-102 (2012)

10. K. M. Sharma, P. S. Sharma, D.Yadav, J. M. Sharma, K. Mohan, Technical suitability of Copper Slag for the Manufacture of Cement. for M/s Sterlite Industries (India) Ltd., Tuticorin (Tamil Nadu) Sponsored Project-1324, July 2005

11. N. Supekar, Utilisation of Copper Slag for Cement Manufacture Construction Management and Review (Sterilite Industries (I) Ltd, Tuticorin, 2007)

12. C. L. Hwang, J. C. Laiw, Properties of Concrete Using Copper Slag as a Substitute for Fine Aggregate, in Proceedings of the 3rd International Conference on Fly Ash, Silica Fume, Slag, and Natural Pozzolans in Concrete, SP-114-82; (1989) p. 1677-1695 